УДК 656.078

КИРИЧЕНКО Г. І., к. т. н., доценТ, БЕРДНИЧЕНКО Ю. А., к. і. н., доцент

(Державний університет інфраструктури та технологій)

\title{
Складові інформаційної моделі перевізного процесу вантажних перевезень залізничного транспорту
}

У статті наведено результати аналізу і теоретичного узагальнення наукових праць, у яких розглядаються проблеми функціонуючої автоматизованої системи залізниці. Розглянуто множину моделей перевізного процесу (інформаційних образів об'єктів управління), яка складає логічну базу даних, щзо забезпечує єдність інформаційного середовища автоматизованої системи керування вантажними перевезеннями Укрзалізниці (АСК ВП УЗ-С). Нормативно-технологічні документи суттєво відрізняються від реальних ситуацій та експлуатаційних умов. Приймати рішення диспетчерський апарат часто вимушений у неочікуваних ситуаціях $i$ в умовах невизначеності. Завдання розвитку IT простору залізниці полягає у розробленні та впровадженні технологій управління оперативною роботою, створенні систем підтримки прийняття диспетчерським апаратом рішення щцодо управління технологічними процесами.

Ключові слова: технологічні процеси залізниці, інформаційні автоматизовані системи, вантажні перевезення, моделі перевізного проиесу, АСК ВП УЗ-С.

\begin{abstract}
Вступ
Транспортний сектор України відіграє важливу роль у соціально-економічному розвитку країни, адже розвинута транспортна система $€$ передумовою економічного зростання, підвищення конкурентоспроможності національної економіки i якості життя населення. Україна має розвинуту інфраструктуру залізничного транспорту, за довжиною мережі залізниць Україна посідає друге місце у Свропі - 21,7 тис. км. На залізницях України функціонують сотні тисяч об'єктів управління, близько однієї тисячі станцій, десятки локомотивних, вагонних депо, дирекції перевезень, дільниці на дирекціях, залізниці, кілька тисяч локомотивів, сотні тисяч вагонів (з кількома десятками їх власників), і все це потребує управління на мережі 21,7 тис. кілометрів. Тому сучасний рівень управління потребує створення апарату точних наук та методів їх використання на практиці, це пов'язано 3 розвитком кібернетики, методів дослідження операцій, які базуються на кількісних характеристиках процесів. Такі характеристики отримуються 3 інформаційних автоматизованих систем.
\end{abstract}

\begin{abstract}
Постановка проблеми
Управління вантажними перевезеннями залізниць України вже не існує без використання автоматизованих систем. Можна констатувати, що всі технології, які розроблюються та впроваджуються у процеси управління, реалізовуються тільки в інформаційному середовищі. Зокрема облік роботи підрозділів і всієї залізниці, розрахунок кількісних та якісних показників роботи підрозділів та всієї залізниці у цілому, фінансова та облікова звітність, технологічні документи, розрахункові документи за надані послуги та ін. відбувається в інформаційній базі - єдиній автоматизованій системі управління вантажними перевезеннями Укрзалізниці (АСК ВП УЗ-С). Система, що містить величезний обсяг даних про всі операції з об'єктами управління, залишається по суті інформаційною. Розробники системи та практики-експлуатаційники наголошують у роботі [1] на необхідності перетворення інформаційної системи у систему підтримки прийняття рішень шляхом створення аналітичних серверів.

Існуючі автоматизовані технології, що використовуються при управлінні процесами перевезень, $€$ в значній мірі системами збору та передачі даних, що часто здійснюються людиною, а отже, із відставанням від реального часу виконання операції, 3 подальшою їх обробкою для складання технологічних, облікових, фінансових документів, звітів про виконану роботу та іншої документації [2-4].
\end{abstract}

ㄷ Г. І. Кириченко, Ю. А. Бердниченко, 2021 


\begin{tabular}{l}
\hline Аналіз останніх досліджень і публікацій \\
\hline Як зазначено у [5], інформаційна система залізниці \\
являє собою гігантське сховище даних, що описують \\
виконану роботу і констатують процеси, що вже \\
відбулись. Довідки та звіти використовуються для \\
аналізу здійсненої роботи. Завдання розвитку ІТ \\
простору залізниці полягає у розробленні та \\
впровадженні технологій управління оперативною \\
роботою, створенні систем підтримки прийняття \\
диспетчерським апаратом рішення щодо управління \\
технологічними процесами (ТП).
\end{tabular}

На жаль, у більшості процесів управління залізничними перевезеннями вантажів, незважаючи на впровадження комп'ютерних технологій на всіх робочих місцях, використовуються підходи, що базуються на евристичних методах, власному досвіді управлінців та дисципліні виконання наказів [6]. Водночас від залізниці, як від сфери обслуговування, бізнес-оточення вимагає прозорості дій, інформаційної відкритості та виконання узгоджених планів. Це все обумовлює необхідність переходу від інформаційної системи, як сховища даних та системи розрахунків документів і звітів, до інтелектуальної системи (IC). У контексті зазначеного серед основних функції IC $[7,8]$ особливо важливі задачі, які базуються на системі підтримки прийняття рішення (СППР) диспетчерським апаратом, задачі планування та прогнозу виконання процесу перевезень, а також управління ТП доставкою вантажів.

Водночас однією з основних тенденцій розвитку IC сьогодні, як показує аналіз світових і вітчизняних досліджень [9-11], є використання автоматизованої розробки програмного забезпечення на основі об'єктно-орієнтованих моделей предметної області та певних семантичних конструкцій. У світі вже існує значна кількість програмних продуктів і технологій класу Business Intelligence (BI) [12], що спрямовані на вибір обгрунтованих рішень на підставі інтелектуального аналізу даних, таких як, наприклад, система Data mining [13]. Згадані технології та системи використовують формалізовані знання про предметну область технологічного циклу - від планування роботи в реальному режимі часу до моделювання ситуацій перевізного процесу.

\footnotetext{
Визначення мети та завдання дослідження

3 метою створення бази знань функціонуючої автоматизованої системи залізниці окремі складові перевізного процесу доцільно надати у вигляді моделей. У контексті цієї статті будемо розуміти під поняттям моделі - інформаційний образ окремих технологічних процесів та основного об'єкта, що є під управлінням системи на відповідному технологічному етапі перевізного процесу. Формування моделей потребує абстрагування від деталей і враховує основні характеристики процесу та об'єкта.
}

Виклад основного матеріалу дослідження

За існуючою технологією функціонування АСК ВП УЗ-С інформація про події з об'єктами управління передається 3 АРМів працівників залізниць до центральної бази даних, де оброблюється, зберігається та утворює окремі моделі перевізного процесу. Умовно відобразимо інформаційний взаємозв'язок технологічних моделей експлуатаційного процесу залізниці.

Множина моделей перевізного процесу (інформаційних образів об'єктів управління) складає логічну базу даних (ЛБД), що забезпечує єдність інформаційного середовища АСК ВП УЗ-С. Моделі зв'язані між собою різними відносинами, але будуються за єдиною формальною схемою.

Кожна модель (іi стан) характеризується множиною атрибутів, які поділяються на групи, що не перетинаються між собою, - грані моделі, вони можуть містити внутрішні грані (підграні). Так, вагонна модель, яка $€$ однією 3 основних моделей системи, містить усі операції з вагоном - від моменту появи цього об'єкта управління на мережі до моменту передачі його на металобрухт. Дані всіх операцій технологічних циклів та нетехнологічних подій зберігаються у сховищі даних для розрахунків та аналізу. Вагонна модель логічно пов'язана 3 відправочною моделлю, де містяться перевізні документи на внутрішні перевезення і дані документів на міжнародні перевезення. Спільною гранню цих моделей $є$ атрибут - вагон та час операції з ним.

Формування всіх даних АСК ВП УЗ-С у типові моделі ТП перевезень та зв'язки між ними забезпечуються дотриманням таких принципів побудови системи, як:

- інтеграція всіх даних системи, що дає можливість обирати будь-яку комбінацію даних різних об'єктів, пов'язаних різними зв'язками;

- відкритість бази даних БД для розширення додавання до БД нової моделі практично не впливає на функціонування вже існуючих;

- типізація та універсалізація процесів запису та читання даних 3 моделей, а також полегшення їх супроводу (розвиток, виправлення помилок тощо).

Можна стверджувати, що АСК ВП УЗ-Є, як інтегроване середовище інформаційних технологій перевізного процесу, є інформаційним простором для впровадження методів управління технологічними процесами та площиною для формування та використання бази знань.

Моделі АСК ВП УЗ-С містять інформацію про події з основними об'єктами управління:

1. Локомотивна модель (локомотиви, поїзди, час роботи локомотивних бригад, дані про ремонт локомотивів).

2. Поїзна модель (інформація про вагони, локомотиви, локомотивні бригади). 
3. Вагонна модель (усі події з вагонами).

4. Модель під'їзних колій (вагони, що $є$ на підприємстві).

5. Модель нарахувань (усі нарахування за перевезення).

6. Відправочна модель (перевізні документи або дані про них).

7. Модель станції (дислокація вагонів по коліях станції).

8. Контейнерна модель (вантаж, що міститься у контейнері у вагоні, контейнер).

9. Модель несправних вагонів (вагон у ремонті).

Моделі перебувають у взаємодії і за строгою ієрархією, відповідно до логічних контролів, та побудовані за вимогами чинних законів, нормативів, наказів, інструкцій тощо (рис. 1).

Моделі зв'язані між собою різними відносинами, але будуються за єдиною формальною схемою, що спирається на чотири базових типи:

- простий об'єкт - не змінюється впродовж усього періоду свого існування (життєвого циклу);
- змінний об'єкт (розвиток простого) - може змінювати свій стан упродовж життєвого циклу;

- рухомий об'єкт (розвиток змінного) - може переміщуватися між полігонами різних стаціонарних об'єктів (змінює дислокацію);

- стаціонарний об'єкт (розвиток змінного) - має полігон, топологічні зв'язки (примикання) 3 полігонами інших стаціонарних об'єктів.

Кожна модель, iї стан характеризується множиною атрибутів, які поділяються на групи, що не перетинаються між собою, - грані моделі, вони можуть містити внутрішні грані (підграні). Склад граней та атрибутів для кожної моделі специфічний, але можуть існувати типові грані та атрибути, які характерні для базового типу у цілому. Таким чином, усі моделі обов'язково включають так звану головну грань, що містить унікальний ідентифікатор об'єкта та його життєвий цикл, усі змінні моделі включають грань операцій з об'єктами даного типу, всі рухомі об'єкти мають дислокаційну грань тощо.

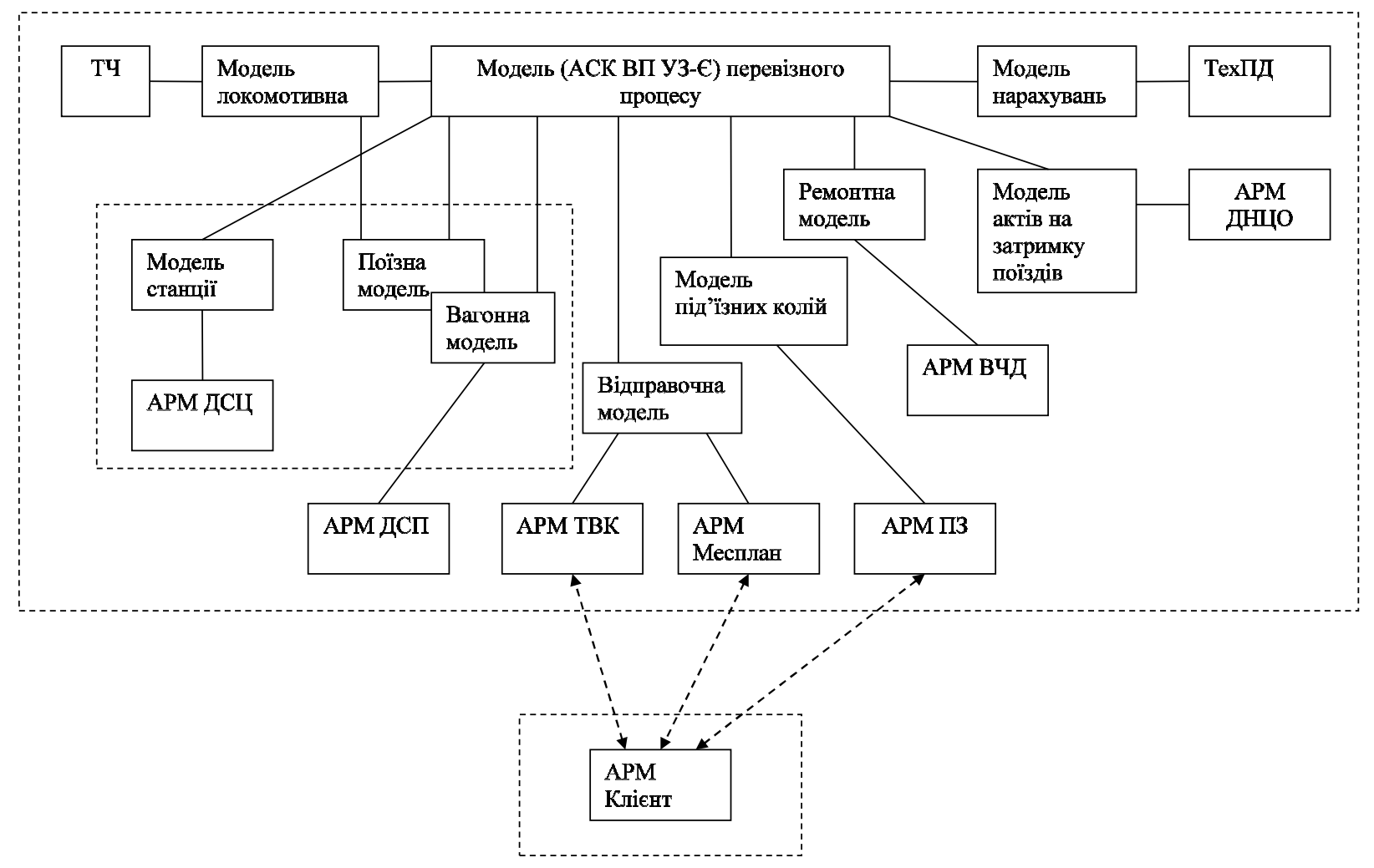

Рис. 1. Моделі АСК ВП УЗ-С

Зв'язки між моделями організовуються чи як посилання із грані однієї моделі на ідентифікатор об'єкта іншої, чи введенням підграні, загальної для двох граней різних моделей. Зведення всіх даних АСК ВП УЗ-С до типових моделей та зв'язків між ними забезпечує:
- інтеграцію всіх даних системи, що дає можливість обирати будь-яку комбінацію даних різних об'єктів, пов'язаних різними зв'язками;

- принципову відкритість бази даних БД для розширення - додавання до БД нової моделі практично не впливає на функціонування вже існуючих; 
- типізацію та універсалізацію процесів запису та читання даних 3 моделей, а також полегшує їх супровід (розвиток, виправлення помилок тощо).

База даних кожного вузла в загальному випадку відображає свій фрагмент технологічного процесу.

База даних АСК ВП УЗ-С утворюється на підставі події 3 поїздом та вагоном, що передаються 3 автоматизованих робочих місць працівників станцій. Час передачі повідомлень має відповідати фактичному часу здійснення технологічних операцій, що не завжди відбувається в реальній експлуатаційній ситуації. Розв'язання задачі своєчасної передачі даних можливе при впровадженні датчиків «напольного» зчитування інформації, систем відеонагляду та інших технічних пристроїв.

Основні події з вагоном, що передаються зі станції до БД, такі:

$t_{l}$ - прибуття поїзда;

$t_{2}$ - списування по прибутті номерів вагонів;

$t_{3}$ - корегування складу поїзда у ТГНЛ для точного розрахунку розміченої ТГНЛ та сортувального листа;

$t_{4}$ - початок комерційного огляду;

$t_{5}$ - початок технічного огляду;

$t_{6}, t_{7}-$ закінчення операцій комерційного та технічного огляду;

$t_{8}$ - маневрові операції з поїздом та корегування складу поїзда;

$t_{8}{ }^{\prime}$ - повідомлення клієнту про прибуття вантажу;

$t_{9}$ - розрахунок технологічних документів для обробки поїзда;

$t_{10}$ - розформування поїзда відповідно до складеного плану сортувального листа на поїзд, що розформовується, (СЛ);

$t_{11}$ - маневрові операції, переставлення вагонів по коліях сортувального парку, корегування моделі сортувальних колій;

$t_{12}$ - подавання вагонів на під'їзну колію, контейнерний майданчик;

$t_{13}$ - подавання несправних вагонів на об'єкти ВЧД;

$t_{14}$ - закінчення накопичення складу поїзда на сортувальних коліях або на сортувально-відправних коліях, розрахунок натурного листа (НЛ) сформованого поїзда;

$t_{15}$ - повернення вагонів після ремонту;

$t_{16}$ - забирання вагонів 3 п/к;

$t_{16}{ }^{\prime}$ - приймання вагона до перевезення;

$t_{17}$ - формування натурного листа на сформований поїзд;

$t_{18}$ - розрахунок довідки машиністу для випробування гальм;

$t_{18}^{\prime}$ - відправлення поїзда;

$t_{19}$ - списування поїзда по відправленню та корегування складу поїзда;

$t_{20}$ - передача інформації про зміну складу поїзда до АСК ВП УЗ-Є для корегування поїзда по прибутті.
Наведена схема (рис. 2) є фрагментом загального інформаційного потоку про події, що відбуваються в експлуатаційних процесах залізниці. Перевізний процес $\epsilon$ однією із найскладніших систем, що визначається множиною залізничних об'єктів, рухомих і стаціонарних, множиною зв'язків між ними. Слід зазначити, що дані про експлуатаційні події, як зв'язки між складними сутностями, мають багатозначні, кардинальні властивості [14]. 


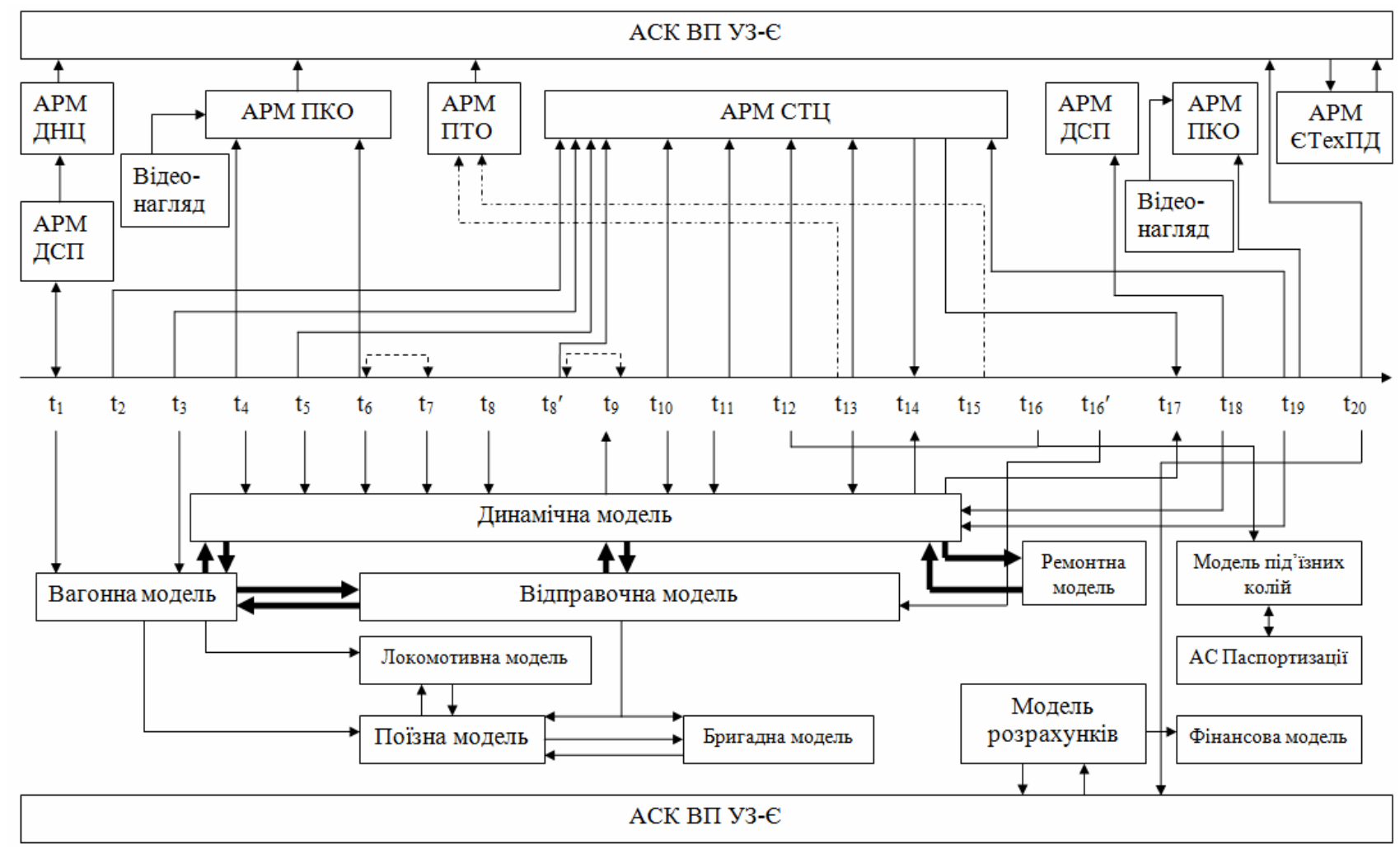

Рис. 2. Фрагмент загального інформаційного потоку про події, що відбуваються в експлуатаційних процесах залізниці

\begin{abstract}
Висновки
Наразі інформаційна система залізниці залишається базою даних для аналізу подій, що відбулися. Управління технологічними процесами передбачає прогнозування подій, завчасне виявлення ситуацій 3 відхилень від прогнозу для прийняття диспетчерських оперативних заходів 3 контролю процесу. Зазначені функції вимагають формування відповідних баз знань. Першим кроком для їх створення є моделювання складових експлуатаційного процесу залізниці та взаємодії залізниці 3 користувачем послуг.

Реалізовувати ефективне диспетчерське управління складною організаційно-технічною системою, яким є залізничний транспорт, неможливо без систем підтримки рішення, що надають рекомендації з управління на підставі моделювання ситуацій.
\end{abstract}

\section{Список використаних джерел}

1. Науменко П. П., Миненко В. Д., Землянов В. Б. АСК ВП УЗ як основа інтеграції автоматизованих систем управління вантажними перевезеннями залізничного транспорту України. URL: stp.diit.edu.ua/article/download/17551/15290
2. Башлаев В. К., Цейтлин С. Ю., Великодный В. В. О создании сетевой автоматизированной системы управления грузовыми перевозками Украины. Вісник Дніпропетровського національного університету залізничного транспорту ім. акад. В. Лазаряна. 2007. Вип. 17. С. 18-21.

3. Цейтлин С. Ю., Коваленко Л. А., Николенко М. В. Создание электронного архива учётных и отчётных форм данных в АСК ВП УЗ-Е. Сучасні інформаційні та комунікаційні технології на транспорті, в промисловості та освіті: тези IX міжнар. наук.практ. конф. Дніпропетровськ, 2015. С. 41.

4. Цейтлін С. Ю., Подоляк С. В., В Василишин І. Д. Передумови створення аналітичної системи. Створення централізованої бази даних фінансовоекономічних систем. Сучасні інформаційні та комунікаційні технології на транспорті, в промисловості та освіті: тези IX міжнар. наук.практ. конф. Дніпропетровськ, 2015. С. 97.

5. Кириченко Г. І. Методика створення інтелектуальної автоматизованої системи управління доставкою вантажів на залізниці. Наука та прогрес транспорту. Вісник Дніпропетровського національного університету залізничного транспорту. 2017. № 2 (68). С. 46-56.

6. Кириченко Г. I. Методологія підвищення ефективності експлуатації засобів транспорту 
шляхом вдосконалення науково-обгрунтованої стратегії управління технологічними процесами: автореф. дис. ... д-ра техн. наук. 05.22.20 експлуатація та ремонт засобів транспорту. Київ, 2021. $40 \mathrm{c}$.

7. Вернигора Р. В., Ельникова Л. О. Перспективы создания интеллектуальной системы поддержки принятия оперативных решений по управлению работой поездных локомотивов на железнодорожном полигоне. Сучасні проблеми розвитку інтелектуальних систем транспорту: тези Міжнар. наук.-практ. конф. Дніпропетровськ, 2014. С. 23.

8. Ломотько Д. В., Бутько Т. В. Методологія формування інтелектуальної транспортної системи на залізничному транспорті. Hayчные mpyдbl SWorld. Иваново, 2012. Т. 2, № 1. С. 45-46.

9. Кириченко Г. І., Габа В. В., Висоцька Г. С. Автоматизований облік часу затримки вагонів та вантажів на підходах до станцій призначення. Залізничний транспорт Украӥни. 2011. № 1. C. 30-32.

10. Di Noia T., Di Sciascio E., Donini F. M. Semantic Matchmaking as Non-Monotonic Reasoning A. Description Logic Approach. Journal of Artificial Intelligence Research. 2007. No. 29. P. 269-307.

11. Fernandez-Loppez M., Gomez-Perez A., Juristo N. Methontology: From Ontological Art Towards Ontological Engineering. Proc. of the Spring Symposium on Ontological Engineering of AAAI. California: Stanford University, 1997. P. 33-40.

12. Гладун А. Я., Рогушина Ю. В. Семантичні технології: принципи та практики. Київ: АДЕФ-Украина, 2016. $308 \mathrm{c}$.

13. Witten I. H., Eibe F., Hall M. A. Data Mining: Practical Machine Learning Tools and Techniques (3rd ed.). Burlington: Morgan Kaufmann, 2011. 664 p.

14. Погромська Г. С. Моделі даних. ER-діаграми. 2019. 33 c. URL: https://www.slideshare.net/pogromskaya/er$\underline{166809727}$

Kyrychenko H. I., Berdnychenko Y. A. Components of the information model of the transportation process of rail freight. The article presents the results of analysis and theoretical generalization of scientific works, which consider the problems of a functioning automated railway system. Management of freight transportation of Ukrainian railways no longer exists without the use of automated systems. It can be stated that all technologies that are developed and implemented in management processes are implemented only in the information environment. In particular, accounting of divisions and the entire railway, calculation of quantitative and qualitative indicators of divisions and the entire railway in general, financial and accounting reports, technological documents, settlement documents for the provision of services and more is in the information base - the only automated freight management system Ukrzaliznytsia. Information about events with control facilities is transmitted from automated workplaces of railway employees to the central database on the transportation process of the automated freight management system of Ukrzaliznytsia, where it processes, stores and forms separate models of the transportation process. These models are virtual. A set of models of the transportation process (information images of control objects) is considered, which is a logical database that ensures the unity of the information environment of the automated freight management system of Ukrzaliznytsia. The consolidation of all data of the automated freight management system of Ukrzaliznytsia to standard models and connections between them provides integration of all data of the system, which allows to choose any combination of data of different objects connected by different connections; the fundamental openness of the database to add a new model to the databases has little effect on the functioning of existing ones; universalization of processes of writing and reading of data from models, and also facilitates their maintenance. Regulatory and technological documents differ significantly from real situations and operating conditions. The dispatching apparatus is often forced to make decisions in unexpected situations and in conditions of uncertainty. The task of the development of the IT space of the railway is to develop and implement technologies for operational management, the creation of systems to support the decision of the dispatching apparatus on the management of technological processes.

Key words: technological processes of the railway, information automated systems, freight transportation, models of the transportation process, ASK VP UZ-E.

Надійшла 28.06.2021 p.

Кириченко Ганна Іванівна, к. $m$. н., доцент, доцент кафедри технологій транспорту та управління прочесами перевезень, Державний університет інфраструктури та технологій, Київ, Украӥна. E-mail: babichanya@ukr.net_ORCID: https://orcid.org/0000-0002$\underline{6883-1877}$

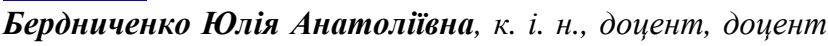
кафедри технологій транспорту та управління прочесами перевезень, Державний університет інфраструктури та технологій, Київ, Украӥна. E-mail: yb08@ukr.net ORCID: https://orcid.org/0000-0001-7536$\underline{7155}$

Kyrychenko Hanna, PhD, Associate professor of the Department of Transport Technologies and Transportation Processes Operation, State University of Infrastructure and Technology. E-mail: babichanya@ukr.net ORCID: https://orcid.org/0000-0002-6883-1877

Berdnychenko Yulia, PhD, Associate professor of the Department of Transport Technologies and Transportation Processes Operation, State University of Infrastructure and Technology. E-mail: $\quad$ yb08@ukr.net $\quad$ ORCID: https://orcid.org/0000-0001-7536-7155 